\title{
Human activity and aeolian relief of Starczynów "Desert", Poland
}

\author{
Jolanta Pełka-Gościniak \\ Department of Physical Geography, Faculty of Earth Sciences, University of Silesia, Będzińska 60, 41-200 Sosnowiec, Poland \\ E-mail address: jp_g@onet.eu
}

\begin{abstract}
Starczynów "Desert” is located in the eastern part of the Silesian Upland (southern Poland) and makes a compact area with the occurrence of aeolian sands, which till the 1960s. were intensively blown. Its flat surface is diversified by many dunes of different shapes and sizes. Aeolian coversands are formed here as a cover of changing thickness. The "desert" is not a typical dry climatic area. The term Starczynów „Desert” refers to the area of occurrence of bare sands and aeolian processes and makes a geographical name that can be found on topographic maps. Its development was conditioned by human activity, where since the Middle Ages dense forest areas have been cut to obtain timber for the needs of contemporary mining and metallurgy of lead and silver ores causing the activation of aeolian processes at sandy substratum, built from the Vistulian proluvial-deluvial deposits. In the formation of the aeolian relief of Starczynów "Desert” it is possible to distinguish some stages of intensive wind activity: the $13^{\text {th }}-15^{\text {th }}$ centuries, the $16^{\text {th }}-17^{\text {th }}$ centuries, the turn of $18^{\text {th }}$ and $19^{\text {th }}$ centuries, the turn of $20^{\text {th }}$ and 21st centuries. In present times human interference in the environment of Starczynów „Desert” consists of fixing sandy areas to protect them from deflation. Human damage exists here in the aeolian relief through terrain levelling and building fire escape roads. In the north-eastern part of the "desert" sand was exploited, therefore a sandpit appeared. This area was subject to the activity of mining for $\mathrm{Zn}-\mathrm{Pb}$ ores, which caused numerous collapsed cones. In the last few years this part of the „desert” was properly reclaimed.
\end{abstract}

KEY WORDS: aeolian processes, deforestation, Silesian Upland

\section{Introduction}

Human being is considered to be one of the most important factors changing the Earth, especially in areas where rich mineral resources occur. One of signs of this activity is cutting large areas of forest, which often leads to the uncovering of the sandy substratum and this facilitates the development of aeolian processes, creating fields for deflation and accumulation of sandy material. The author focuses on presenting how anthropogenic pressure has influenced the formation of aeolian relief in Starczynów „Desert”.

\section{Study area}

Starczynów „Desert” is located in the eastern part of the Silesian Upland (southern Poland) and occupies the southern part of the widely understood Błędów Desert (KozIOŁ, 1952) of small area (about
$5 \mathrm{~km}^{2}$ ) located between Bukowno in the west and Olkusz in the east. From the north it is limited by the Baba river, from the south-west by the Sztoła river, from the east and south-east by the Upper Jurassic $\left(\mathrm{J}_{3}\right)$ cuesta (Fig. 1).

The age and genesis of sandy deposits of this area was the subject of many studies. The majority of authors consider that sands were accumulated here during the Middle Polish glaciation (e.g. KozioŁ, 1952; GILEWSKA, 1972). LEWANDOWSKI \& ZIELIŃSKI (1990) relate the age of these deposits to three glaciations: Oder, Warthe and Vistulian.

The genesis of sands in the eastern part of the Silesian Upland is complicated, because there can occur deposits of fluvioglacial origin (e.g. Kozıø, 1952; GILEWSKA, 1972), fluvial-proluvial (e.g. SZCZYPEK \& WACH, 1989; LEWANDOWSKI \& ZIELIŃSKI, 1990), fluvial, proluvial-deluvial (SENDOBRY \& SZCZYPEK, 1991). Therefore it is possible to assume that deposits in the neighbourhood of Olkusz are of 
fluvial-proluvial origin (LEWANDOWSKI \& ZIELIŃSKI, 1990; SZCZYPEK ET AL., 1994).

On the basis of earlier studies by the author (PEŁKA, 1994; PEŁKA-GoŚCINIAK, 1999, 2000a) consisting of the analysis of meteorological data and results of field measurements it is possible to state, that the study area was mostly subject to winds from the widely understood western sector.

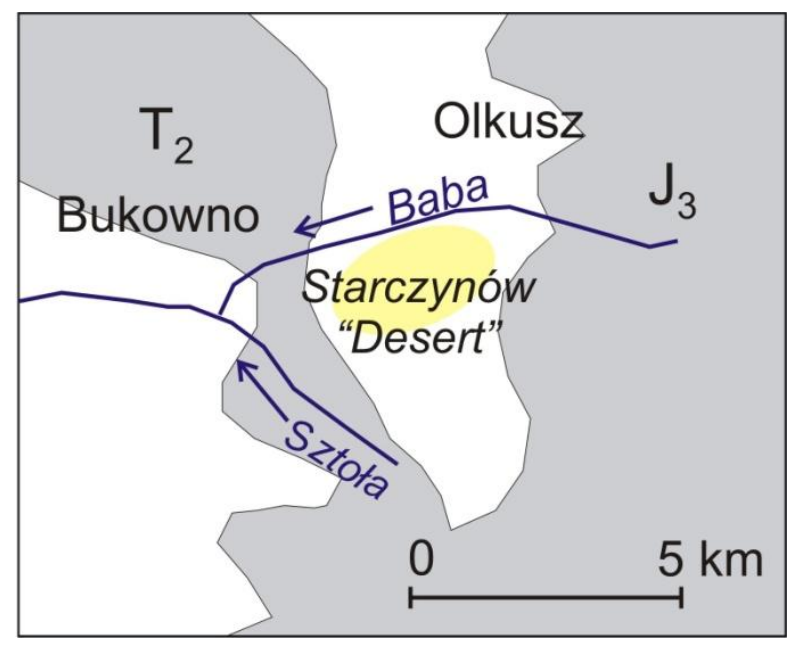

Fig. 1. Location of Starczynów „Desert”

\section{Methods of research}

To achieve the intended aim the author conducted many studies of inhouse and field character. Inhouse investigations consisted of collecting and analysing source materials: available literature and topographic maps from different time periods, whereas field investigations consisted in making geomorphological surveys and drawing a geomorphological sketch of the study area.

\section{Aeolian relief of Starczynów „Desert”}

Starczynów „Desert” makes a compact area of occurrence of aeolian sands. Its flat surface is diversified by many dunes of different shapes and sizes. Dunes are grouped into distinct parallel belts (Fig. 2). In the neighbourhood of the cuesta they change character and occur in a form of small, irregular dunes of meridian course. The most distinct is the central dune belt, where longitudinal dune predominates. This belt divides the "desert" into two parts - northern and southern. To the northern part belong the transverse dune located in the west of the study area and numerous but small logitudinal dunes occurring in the northeastern part of the "desert", whereas to the southern part - large barkhan-like dune and numerous depressions without drainage of different shapes and sizes (PEŁKA-GoŚCINIAK, 1996). It is possible to state, that the northern part has a mostly accumulative character, whereas the southern part - rather deflative. Aeolian coversands in the area of the whole "desert” are formed as a cover of changing thickness (Fig. 3). They are characterised by monotonous, slightly waved surface, varied by shallow and rather irregular depressions and small hillocks (PEŁKA-GOŚCINIAK, 2000a).

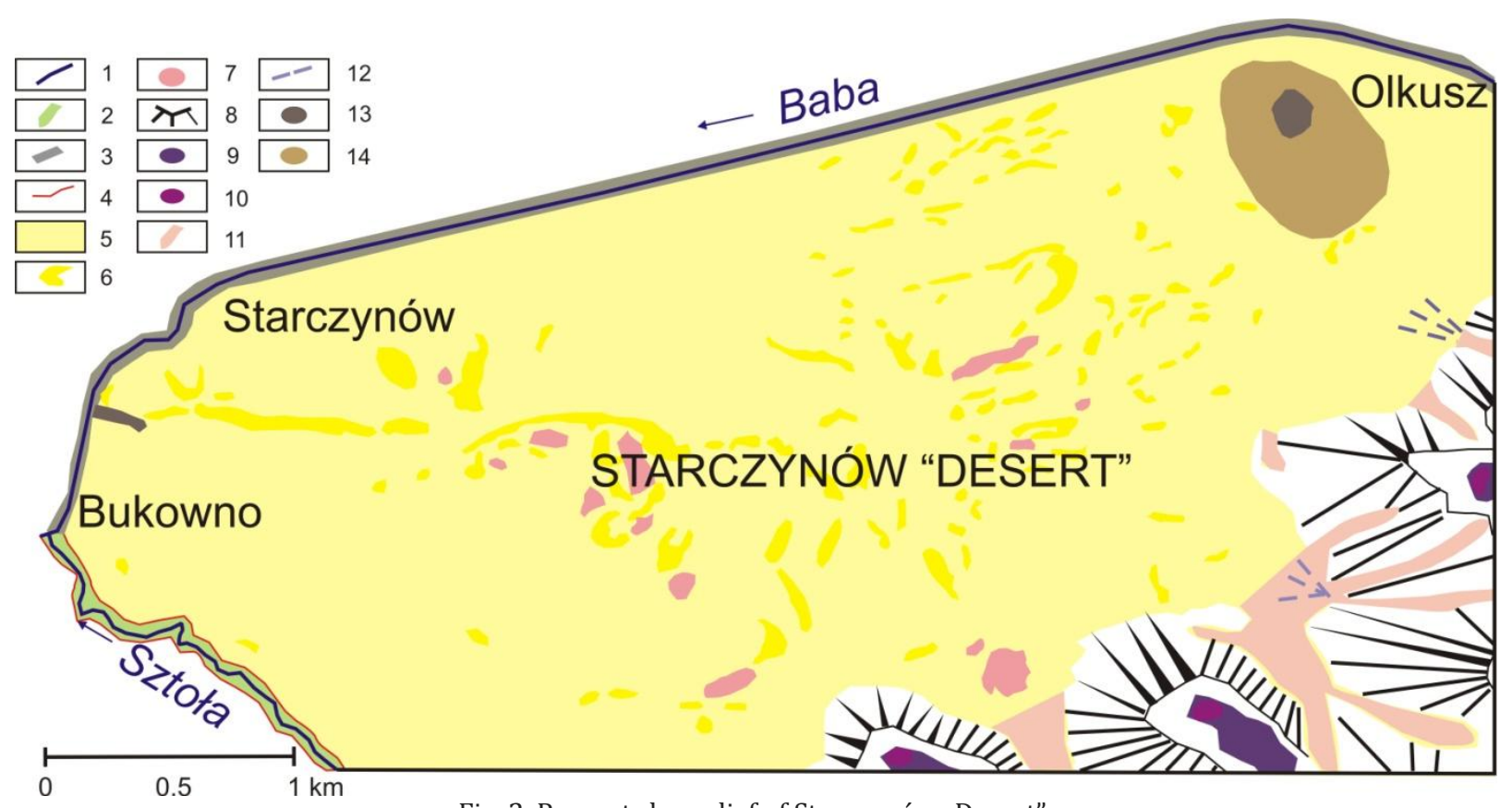

Fig. 2. Present-day relief of Starczynów „Desert”

1 - rivers; 2 - river valleys; 3 - concreted river channel; 4 - erosional scarps; 5 - aeolian coversands; 6 - dunes;

7 - depressions without drainage; 8 - slopes; 9 - flat-topped surfaces of slopes; 10 - karstic relict hills; 11 - alluvial fans;

12 - erosional-denudational valleys; 13 - reclaimed area after collapse cones; 14 - reclaimed area of sandpit 


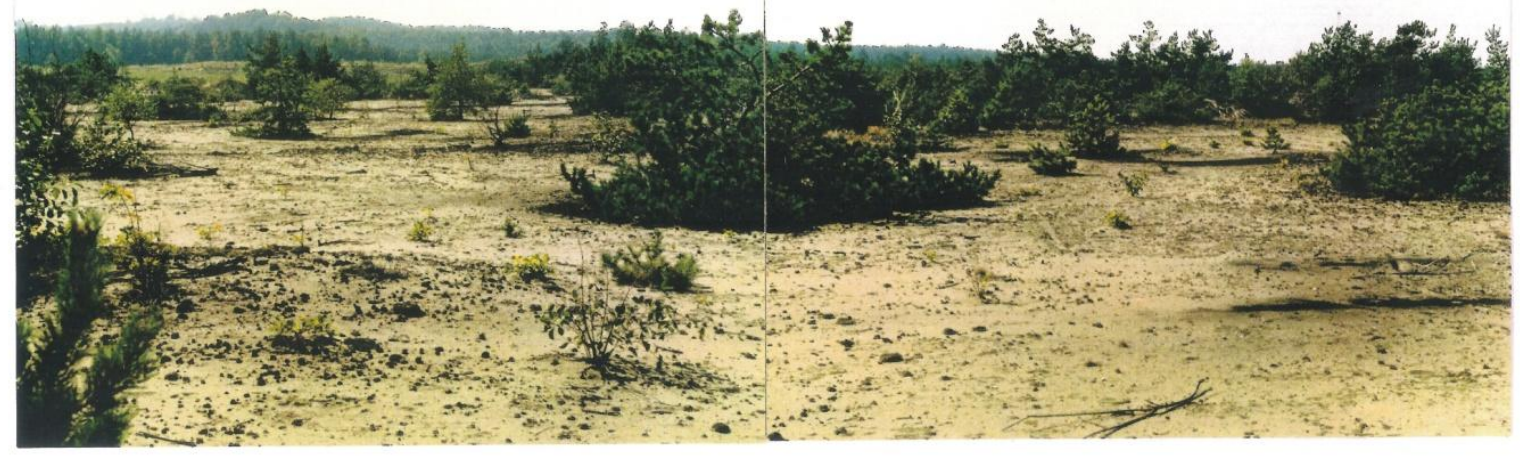

Fig. 3. Aeolian coversands in Starczynów „Desert” (J. Pełka-Gościniak)

\section{Human activity and aeolian relief of Starczynów „Desert”}

At the end of the Pleistocene and in the Holocene wind activity in the Starczynów "Desert" caused the transformation of features of sandy deposits and the formation of numerous aeolian landforms (PEŁKA, 1992; PEŁKA-GoŚCINIAK, 2000a, b). Before the $12^{\text {th }}$ century this area was covered by dense forests (MICHALIK, 1985). Later the forest cover was disturbed and sandy substratum was uncovered due to demand for timber to heat in contemporary lead and silver works located in the neighbourhood of Olkusz. According to documented historical data in the mid-13th century in this region the local population exploited deposits of ores occurring in the Middle-Triassic ore-bearing dolomites (e.g. ŁABĘCKI, 1841; STASZIC, 1955; MOLENDA, 1963; KIRYK \& KOŁODZIEJCZYK, 1978; KŁYSIŃSKA, 1985; Szczypek \& Wach, 1991; RAHMONOW, 1999; PE七KAGOŚCINIAK, 2000b; DULIAS ET AL., 2008 and others). Intensive mining and metallurgy developed here in the $13^{\text {th- }}-15^{\text {th }}$ centuries required large amounts of timber for melting processes and for timbering of deep shafts and the only material for ore melting was charcoal. Therefore it is clear that the neighbouing forests provided the source material for this production. Destroying the forests and the uncovering of sandy deposits caused the activation of aeolian processes under the influence of westerly winds (PEŁKA-GoŚCINIAK, 2000b).

So, it is possible to assume that the Starczynów "Desert" could be formed in that period. It is confirmed by the occurrence of aeolian deposits. The beginning of the accumulation of these deposits happened in the mid-15th century, which is proved by the age of charcoal ( $480 \pm 50 \mathrm{BP}$ ) (Gd-4253), occurring at the floor of the layer of nearquesta sandy deposits (SENDOBRY \& SZCZYPEK, 1991). The aeolian relief formed in that period remained during the following centuries.
The next stage of intensification of the aeolian processes occurred in the latter part of the $16^{\text {th }}$ century due to water draining by means of draining adits. It caused the further cutting of forest in order to obtain the timber for the necessary equipmenttimbering, gins, trays and roofs (ABT, 1957). Owing to uncovering the sands were activated again and the earlier aeolian relief was remodelled. This process was additionally facilitated by overdried deposits of substratum as a result of the lowering of the ground water horizon connected with adit building.

The end of the $17^{\text {th }}$ and the beginning of the $18^{\text {th }}$ centuries are considered to be the period of complete collapse of ore mining in the region of Olkusz. In that period the vegetation succession and fixing of existing aeolian relief could have taken place.

At the turn of the $18^{\text {th }}$ and $19^{\text {th }}$ centuries the mining works were intensified owing to the zinc metallurgy and this was the reason for the renewal of deforestation there. In that period sands started to cover up plough lands and yards in front of houses from the south and the south-west. This was why the head of the administrative district asked the Radom governor to carry out the necessary planting of pines at dunes surrounding the town (MOLENDA, 1963; RAHMONOW, 1999).

In 1815 Stanisław Staszic wrote: Olkusz is an immeasurable eye surrounded by the sand sea, whereas in 1841 year $Ł A B E$ CKI reported, that it is difficult on the Polish land to find places less fertile and more similar to desert than the neihhbourhood of Olkusz (DULIAS ET AL., 2008). This statement is fully confirmed by Karta geognostyczna Zagłębia Węglowego w Królestwie Polskim made by HEMPEL in 1856 (Fig. 4).

In 1902 WYEBERG referred to the description of ROEMER (1870): To the south of village of Starczynów (6 versts from Olkusz) sandy dunes rise. They are 10-20 feet high and loosely covered by pine forest. 
Beyond them a wide sandy plain, devoid of vegetation extends, at a distance of a $1 / 4$ to $3 / 4$ of a mile from the dunes it is surrounded by pine forest. In such a form this picture was presented in
"Płastowaja karta polskowo kamiennougolowo basiejna" made by Gatowski and ŁEMPICKI in 1891 (Fig. 5) and "Spezialkarte der ÖstereichhischUngarischen Monarchie” from 1906 (Fig. 6).

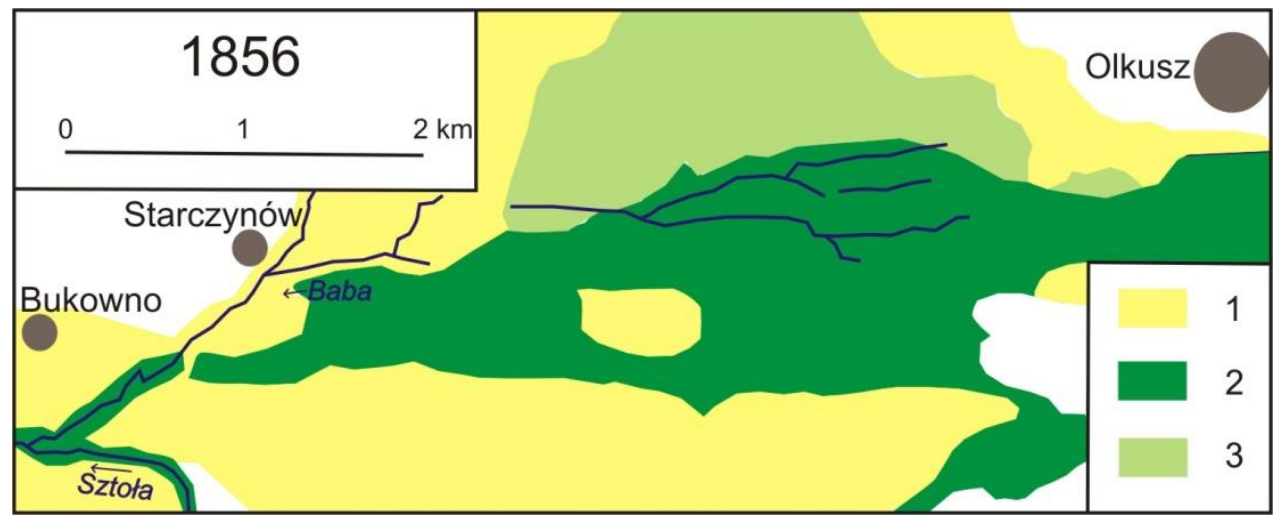

Fig. 4. Area of Starczynów „Desert” in 1856 (on the base of Karta geognostyczna Zagłębia Węglowego w Królestwie Polskim made by Hempel)

1 - sandy areas without vegetation; 2 - forests; 3 - sandy areas with rare vegetation cover

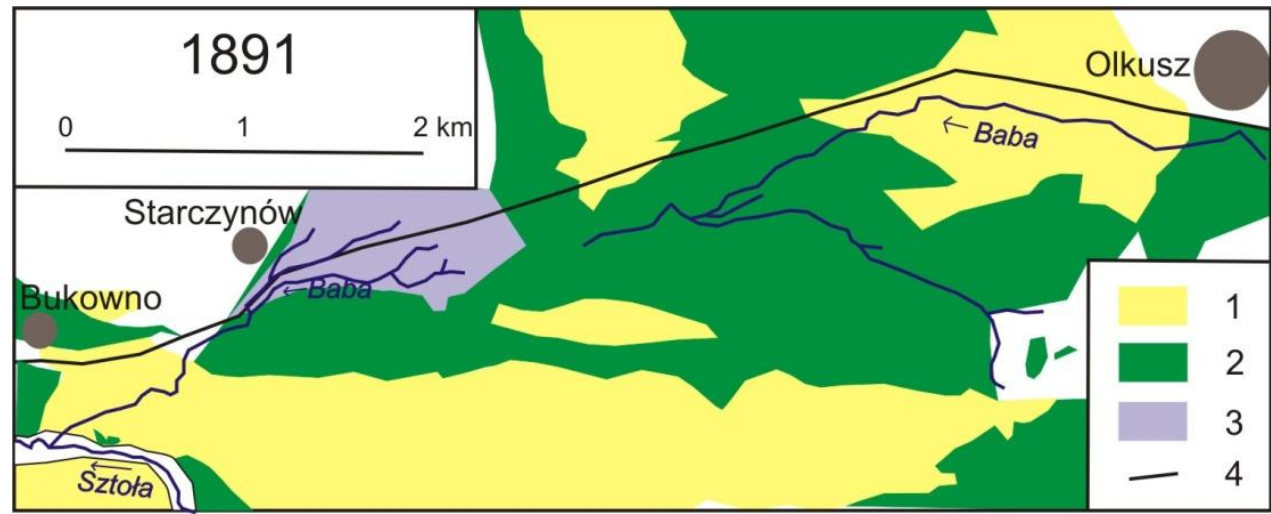

Fig. 5. Area of Starczynów „Desert” in 1891(on the base of Płastowaja karta polskowo kamiennougolowo basiejna made by Gatowski and Łempicki)

1 - sandy areas without vegetation; 2 - forests; 3 - water-logged areas; 4 - railway line

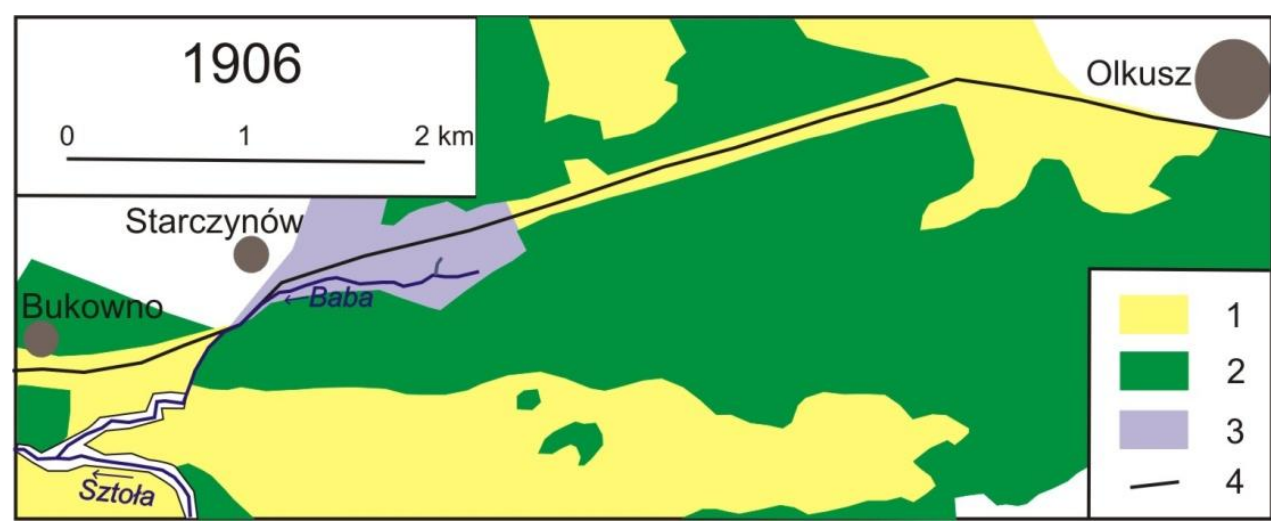

Fig 6. Area of Starczynów „Desert” in 1906 (on the base of Spezialkarte der Östereichhisch-Ungarischen Monarchie) 1 - sandy areas without vegetation; 2 - forests; 3 - water-logged areas; 4 - railway line

In the 1920s. and 1930s. the "desert” still remained as an area of drift sands (SUJKOWSKI, 1928), which covered the trees located at the desert borders up to $2 / 3$ of their height. Sometimes only the upper parts of tree branches protruded from the sand (BĄK, 1968). At that time STECKI (1935) wrote, that to the south-west of Olkusz spreads a sand belt called by local people as "trashy sea" because an illusive mirage in the form of a sheet water was observed here.

In the 1940s. and 1950s. the study area was still subject to the free wind activity. STRóżECKI (1991), 
referring to the description of SosNowski from 1955 informed us that at the surface of the Starczynów sands there are small terrain waves and ups and downs, and at its borders there are large dunes and cones over the branching pines. Large branches of these trees bite into the sand by claws of long, protruding roots, which give them the strength to fight against overpowering strong winds and dry sand storms. And they are frequently transformed into rising whirl sand-spots and clouds, which shut out the view like fogs and vapour over water. The section of road connecting Bukowno and Olkusz and cutting the "desert" at a distance of more than $1 \mathrm{~km}$, is sometimes covered together with ditches by sandy hurricanes as flat as snow storms...

In 1974 LITEWKA informed us, that the surface of Starczynów "Desert” is almost even, diversified in some places by dunes and cones of sand enclosed by vegetation, that protects from translocation despite sand-spouts sometimes whirling here.

Therefore it is possible to state, that even in the 1950s. the Starczynów "Desert” made the bare area of drift sands, which were freely blown out here (RADOSZ, 1991). In the mid-20th century the interference of human activity in this area consisted of the fixing sandy surfaces by introducing vegetation planting. Despite numerous attempts at planting the vegetation increase was limited because of the character of the parent rock and air pollution. Effects of these activities were very small pines Pinus sylvestris, Caspian willow Salix acutifolia, downy mountain willow Salix arenaria, grey alder Alnus incana and common birch Betula pendula (BĄK, 1968).

After fires in 1992 and 2013 the Starczynów "desert" could be a potential deflation field for a short time. The uncovered substratum was again subject not only to deflation but also to the processes of rill- and sheet-wash (PEŁKA-GOŚCINIAK, 2000a).

The slow rebuilding of the tree stands is hindered by a low natural soil fertility, strong contamination by heavy metals and the occurrence of depressive cones.

\section{Conclusions}

The development of aeolian relief of Starczynów „Desert" was conditioned by human activity. Since the Middle Ages it has been subject to human pressure. Deforestation by humans caused the uncovering of a sandy substratum, creating conditions for activation of wind processes. Aeolian factor caused the origination of various accumulation and deflation landforms, which were remodelled and transformed many times
(DULIAS ET AL., 2008). In the formation of aeolian relief of Starczynów Desert it is possible to distinguish the following stages:

(1) $13^{\text {th }}-15^{\text {th }}$ centuries - intensification of wind activity owing to wasteful forest economy to gain charcoal for needs of metallurgy of silver and lead ores,

(2) $16^{\text {th }}-17^{\text {th }}$ centuries - animation of aeolian activity at bare sandy substratum due to renewed forest cutting for the needs of adit building,

(3) the turn of the $18^{\text {th }}$ and $19^{\text {th }}$ centuriesactivation of aeolian processes as a result of deforestation for newly conducted mining due to inventing zinc technology,

(4) the end of the $20^{\text {th }}$ century and the beginning of the $21^{\text {st }}$ century - area of desert as a potential deflation field as a result of extensive forest fires. The occurrence of natural wind processes in a sandpit. (PEŁKA, 1994; PEŁKAGoŚCINIAK, 1999, 2000a).

In present times the human interference in the environment of Starczynów "Desert” consists of the fixing sandy areas to protect them from deflation. Damage by humans existed here in the aeolian relief through terrain levelling and building of fire escape roads. In the north-eastern part of the "desert" sand was exploitated, so a sandpit appeared. This area was subject to the activity of mining of $\mathrm{Zn}-\mathrm{Pb}$ ores, which effects were numerous collapsed cones. In the last years this part of the „desert" was properly reclaimed (WPŁYW..., 2012).

\section{References}

Abt E.L.G. 1957. Memoriał w sprawie kopalnictwa ołowiu i srebra na Górnym Śląsku. Katowice.

Bąk K. 1968. Wzrost i przydatność drzew i krzewów wprowadzonych przy zalesianiu Pustyni Starczynowskiej. WSR, Kraków, maszynopis.

Dulias R., Pelka-Gosciniak J., Szczypek T. 2008. Influence of human activity on the development of aeolian processes in the Silesian-Cracow Upland (Poland). Zeits. Geomorph., 52: $15-33$

Gatowski A., Łempicki M. 1981. Płastowaja karta polskowo kamiennougolowo basiejna, 1:10 000, Zbiory kartogr. Arch. Państ. w Katowicach.

Gilewska S. 1972. Wyżyny Śląsko-Małopolskie. [in:] Klimaszewski M. (ed.) Geomorfologia Polski, PWN, Warszawa, 1: 232-339.

Hempel J. 1856 Karta geognostyczna Zagłębia Węglowego w Królestwie Polskim, 1:20 000, Zbiory kartogr. Arch. Państ. w Katowicach.

Kiryk F., Kołodziejczyk R. (ed.) 1978. Dzieje Olkusza i regionu olkuskiego. PWN, Warszawa-Kraków.

Kłysińska J. 1985. Olkusz. Niezwykła historia górniczego miasta. Poznaj Swój Kraj, 7: 3-7.

Kozioł S. 1952. Budowa geologiczna Pustyni Błędowskiej. $Z$ badań czwartorzędu $w$ Polsce. Biul. PIK 65, t. 1, Warszawa: 383-416.

Lewandowski J., Zieliński T. 1990. Wiek i geneza osadów kopalnej doliny Białej Przemszy (Wyżyna Śląska). Biul. IG, 364: 97-126. 
Litewka Cz. 1974. Polska Sahara. Aura, 3: 31-33.

Łabęcki H. 1841. Wiadomość bibliograficzna o górnictwie $w$ Polsce i naukach przyrodniczych ścisły związek $z$ nimi majacych. Warszawa.

Michalik S. 1985. Pustynia Błędowska. Poznaj Swój Kraj, 7: 18-22.

Molenda D. 1963. Górnictwo kruszcowe na terenie złóż ślaskokrakowskich do połowy XVI wieku. Ossolineum.

Pełka J. 1994. Rekonstrukcja lokalnych warunków anemologicznych we wschodniej części Wyżyny Śląskiej na podstawie analizy eolicznych form terenu i drzew sztandarowych. [in:] Nowaczyk B., Szczypek T. (eds.) Vistuliańsko-holoceńskie zjawiska $i$ formy eoliczne (wybrane zagadnienia). SGP, Poznań: 57-67.

Pełka-Gościniak J. 1996. Cechy strukturalne i teksturalne wydmy barchanopodobnej na Pustyni Starczynowskiej. [in:] Szczypek T., Waga J.M. (eds.) Współczesne oraz kopalne zjawiska i formy eoliczne. Wybrane zagadnienia. WNoZ UŚ, PK CKKRW, SGP, Sosnowiec: 111-118.

Pełka-Gościniak J. 1999. Influence of wind and older relief on the character of sandy deposits in the Starczynów "Desert” (southern Poland). [in:] Schirmer W. (ed.) GeoArchaeoRhein, Münster, 3: 163-176.

Pełka-Gościniak J. 2000a. Przestrzenna zmienność piasków eolicznych Pustyni Starczynowskiej. WNoZ UŚ, Sosnowiec.

Pełka-Gościniak J. 2000b. Development of aeolian relief in areas transformed by human impact (a case study of Bukowno neighbourhood-eastern part of Silesian Upland) [in:] Dulias R., Pełka-Gościniak J. (eds.) Aeolian processes in different landscape zones, UŚ, SGP, Sosnowiec, 129-142.

Radosz J. 1991. Kształtowanie się krajobrazu we wschodniej części Wyżyny Śląskiej pod wpływem gospodarczej działalności człowieka. Kształt. środ. geogr. i ochr. przyr. na obsz. uprzem. i zurb., 3: 13-20.

Rahmonow O. 1999. Procesy zarastania Pustyni Błędowskiej. WNoZ UŚ, Sosnowiec.

Rahmonov 0. 2007. Relacje między roślinnością i glebq w inicjalnej fazie sukcesji na obszarach piaszczystych. UŚ, Katowice.
Roemer F. 1870. Geologie von Oberschlesien. Breslau.

Sendobry K., Szczypek T. 1991. Geneza i wiek podkuestowych osadów piaszczystych w okolicach Olkusza. Geogr. Stud. et dissert., UŚ Katowice: 15: 88-104.

Sosnowski K. 1955. Jura Krakowsko-Wieluńska. SiT.

Spezialkarte der Östereichhisch-Ungarischen Monarchie, 1906: 4 sekcje, 1:75000, zdjęcie terenowe $\mathrm{z}$ lat 1873-1890, Vien, Zbiory kartogr. Arch. Państ. w Katowicach.

Staszic S. 1955. O ziemiorodztwie Karpatow i innych gor $i$ rownin Polski. Wyd. Geol, Warszawa.

Stecki K. 1935. Miraże w Pustyni Błędowskiej. Wszechświat, 6: $165-168$

Stróżecki A. 1991. Przez piaski pustyń Starczynowskiej i Błędowskiej. Gościniec, 23, 4: 25-26.

Sujkowski Z. 1928. Uwagi o piaskach i lessach w Olkuskiem i ich wzajemnym stosunku. Spraw. z posiedzeń Tow. Nauk. Warsz., 21, 1-2.

Szczypek T., Wach J. 1989. Accumulation phases of the Quaternary deposits in the Błędów Desert based on lithological studies. Quast. Geogr., SI, UAM, Poznań, 2: 137-145.

Szczypek T., Wach J. 1991. Human impact and intensity of aeolian processes in the Silesian-Cracow Upland (Southern Poland). Z. Geomorph. N.F., Berlin, Stuttgart, 90: 171-177.

Tyc A. 1989. Współczesne procesy krasowe w strefie oddziaływania kopalń olkuskiego okręgu rudnego. Kras $i$ speleologia, 6 (15): 23-39.

Tyc A. 1990. Formy zapadliskowe w krasie Olkuskiego Okręgu Rudnego wywołane działalnością górniczą i pompowaniem. Zesz. Nauk. AGH, Sozologia i Sozotechnika, 32 99-112.

Weyberg Z. 1902. Piorunki. Wszechświat, 1: 4-7.

Wpływ działalności górniczej na gospodarkę leśna Nadleśnictwa Olkusz, Protokół ze Wspólnego Posiedz. Rad Gosp. Wod. Regionów Wodn. Małej Wisły i Górnej Odry oraz Stałych Komisji ds. Udziału Społeczeństwa przy Radach, 20.09.2012, Starostwo Powiatowe w Olkuszu. 